\title{
Cities, corporeality and consciousness
}

\author{
Ward, Graham ${ }^{1}$ \\ Stellenbosch University \\ graham.ward@theology.ox.ac.uk
}

\begin{abstract}
:
This article seeks to explore the connections between our ability to live and work with symbols, our nature as a symbolic species, our physiologies, and our theologies, by examining the phenomenon of the (modern) city. It proposes that cities could be conceived of as 'corporate' expressions of human consciousness, that are founded on and continuously aim to purvey certain images and myths. These images and myth, it is argued, has been profoundly the work of a theological imagination. In an attempt to understand our modern (and seemingly secular) cityscapes, this article accordingly sets out to uncover some of the the particular theologies they articulate.
\end{abstract}

\section{Keywords:}

Cities, consciousness, corporeality, transcendence, theological imagination, eschatology.

At British airports at the moment the banking group HSBC are running a series of adverts informing us about the future. In one of these adverts there is an outline of the human brain divided into various segments by coloured lines. The logo reads: "In the future transport networks will think for themselves". Three quite difficult fields of knowledge are being superimposed in this advert: first, the traffic flows in and around a city; secondly, the electronic circuitry of a computer; and thirdly the neural networks of the brain that relate, electro-chemically, discreet functions. From the imposition of these three fields a leap is made by the words "think for themselves." The leap is the whole point because what is suggested is that the modern notion of the city as a machine ${ }^{2}$ is giving way to a new simile -

1 Graham Ward is regius Professor of Divinity, Christ Church, Oxford

2 There are many conceptions of the city that have inspired urban planners, architects and critical reflections upon the city as human beings' most ambitious art form. There 
the city as a living organism with its own consciousness. ${ }^{3}$ The cities of the future will have minds of their own. Well, that's the suggestion. Cities will think for themselves and in doing that the traffic will flow in ways more sensitive and responsive to both the environment and the contingency of conditions. Like bodies they will respond and adapt quickly to regulate life, seeking maximal benefit.

The image reflects something of a cultural shift. Recall the work on AI by the eminent director of the MIT media lab, the architect Nicholas Negroponte. ${ }^{4}$ Through the 70s until the turn of the twentieth century his Architecture Machine Group was working with MITs famous artificial intelligence projects to develop intelligent spaces - houses, rooms, buildings in which human beings and computers interacted, inter-faced. But time has moved on: physics is becoming integrated into biology, artificial intelligence has become bio-inspired, and descriptions of the brain as computers (in the work of figures like Daniel Dennett ${ }^{5}$ and Marvin Minsky ${ }^{6}$ ) is being recognised by neuroscientists like Antonio Damasio ${ }^{7}$ and Raymond Tallis ${ }^{8}$ as profoundly misleading.

And, of course, the statement that transport networks will think for themselves can only be metaphorical. They will have to be made, designed,

are Garden Cities (Ebenezer Howard), aesthetic, monument cities (Daniel Burnham), cities conceived as utopian machines (Le Corbusier) and cities of enterprise (James Rouse). For an overview see Peter Hall, Cities of Tomorrow: An Intellectual History of Urban Planning and Design in the C20th (Oxford: Blackwell, 1996).

3 In recent years, among neuroscientists and philosophers treating the relationship (and difference) between the brain and the mind) there has been a critique of the way computing programming practices and AI provided reductive models for cognitive processing.

4 See Nicholas Negroponte, Being Digital (New York: Knopf, 1999).

5 Daniel C Dennett, Consciousness Explained (London: Penguin Books, 1993). See also, John Searle, "Minds, Brains, and Programs", Brain and Behavourial Sciences 3(4) (1980), 417-57.

6 Marvin Minsky, The Emotion Machine: Commonsense Thinking, Artificial Intelligence, and the Future of the Human Mind (New York: Simon \& Schuster, 2007). See also, Chris Frith, Making up the Mind: How the Brain Creates Our Mental World (Oxford: Blackwell, 2007).

7 Antonio Damasio, Self Comes to Mind; Constructing the Conscious Brain (London: Vintage Books, 2012).

8 Raymond Tallis, Aping Mankind: Neuromania, Dawinitis and the Misrepresentation of Humanity (Durham: Acumen, 2011). 
to think for themselves by human beings. The networks will only be as 'intelligent', that is, interfacing with the various environments and conditions, as the software designers can make them. ${ }^{9}$ Nevertheless, I would like to explore a possibility that this move towards these bio-inspired and neuroscientific modelling of our urban materialities suggests. I'm going to raise a question, not because I can answer it and not because this essay is an attempt to answer it, but it will indicate what I'm pointing towards. The question is: What is the connection between our ability to live and work with symbols, our nature as a symbolic species ${ }^{10}$, our physiologies, and our theologies? That there is a connection is not in doubt: we who work have devised and worked with tools, conceived and built the environments in which we live, and we do so in and through our bodies; bodies that have adapted and evolved to be what they are - and what they will be. They articulate theologies written deep into the fabric of those environments; theologies still present in today's cities and theologies increasingly present in the manifestations of globalisation in those cities. I want to get at those connections, and the theologies they articulate. So, at its most abstract, I'm asking a question about the relation between our physiologies as they continually process the environments in which we are situated, the technology we produce in that process (including our symbol-making), our consciousness (civic and global), and our theological imaginings. But I want to get at something less abstract than all that sounds.

Settled life in long-term and identifiable communities goes back to around 10,000-8.500 years ago when hunter-gatherers became sedentary. ${ }^{11}$ The first cities that arise from this non-nomadic existence and the built environments they required comes much later. ${ }^{12}$ But the possibility for the new agrarian

9 This is totally unlike the interface between bodies and the world in which they are situated. For the body, there is no inside/outside, but a continuum in which reception and response are not neatly divided operations, nor one-way. Our bodies are in a continuous communication loops with the environment, and the environment with our bodies.

10 For a detailed examination of how human beings, as distinct from other animals and primates, are a symbol using species see Terrence W Deacon, The Symbolic Species: The Co-evolution of Language and the Brain (New York: W.W.Norton, 1997).

11 See David Lewis-Wallace and David Pearce, Inside the Neolithic Mind (London: Thames \& Hudson, 2005) on Nevali Cori, Göbekli Tepe and Çayönü.

12 Cities like the Biblical Jericho, excavated by the archaeologist Dame Kathleen Kenyon from the 1950s and dating as site for domesticity around 7,300-6,000 BC 
living and their urban centres, begins much further back, to around 2.2 million years ago when hominids first began to make tools, because the ability to create a built environment has to begin with the ability to recognise and conceive the way the potential (in a rock, in a stick, in any material whatsoever) can be used, harnessed, developed, and adapted in ways that enhance and extend human abilities; securing for them a better environment for reproduction and security from threat. The rock, the stick, whatever the material is, is not just seen, it is seen as something it is not yet but can be made to $b e .{ }^{13}$ There is not just perception operative here. There is also anticipation and imagination, knowledge of the nature of the thing to be used, and an understanding of how that new use might be indeed improve conditions. In the encounter between the physiological responses of the human body in its habitat and a material object, consciousness, thought, issues.

Now some eliminative materialists have wished to see this consciousness as epiphenomenal - an accident and not even particularly important byproduct of the electro-chemical excitation of the brain. Consciousness is an unlooked for effect the cause of which are the flows of bio-molecular information through the multiple dendrites and synapses of the neuron. But this is a hypothesis at best which explains very little. An effect, as Newton and Hume pointed out long ago, has to bear a direct relation to its cause; an inductive relation. But there is no obvious inductive relation between the material workings of our neural networks and the invisibility of thought. There is a major qualitative difference here between the material and the mental, and this qualitative difference is evident, indeed paramount, whenever there is a material adaptation made to our environment: whether that adaptation is a stone-axe or a sewage system. Any number of neuroscientists point to this qualitative difference but find it difficult to give an account of how it occurs. But we have to acknowledge the results of that occurrence in all our building, manufacturing and fashioning.

I am not going to provide an account myself. I don't have the expertise, but I want to point to a similar qualitative leap from the material to the mental in the creation of our cities. And I want to suggest further that this leap has something to do with a human capacity to transcend the material and,

13 For an account of how seeing as is related to belief and imagination, see Graham Ward, Unbelievable: Why We Believe and Why We Don't (London: IB Tauris, 2014). 
indeed, think through the experience of that transcendence itself. First: a word about 'transcendence'. This can only begin with the recognition of a separation; a consciousness of what I, as a perceiving body, am not. I am not that tree, this boulder, the animal I am hunting, the rain on the savannah that I smell. I am distinct from my environment. As I said above, the body does not have an internal and an external as a biological organism. The distinction between me as an object with respect to other objects surrounding me comes, then, with consciousness. Consciousness is the first step towards transcendence. The second step is self-consciousness: an awareness of myself as a consciousness related both in itself and also for itself. Hegel mapped this phenomenological terrain and the interaction involved in the early C19th. ${ }^{14}$ Cities are 'corporate' expressions of human consciousness and our ability to transcend (and adapt) our environment. I emphasise corporate rather than collective because individual bodies participate in large organic bodies such that there is a co-belonging. Cities also facilitate our individual and corporate reflections upon the nature and perhaps theological telos of consciousness. And they do this because cities create a consciousness that we both contribute to as citizens and inhabit. At times cities can also create 'emotional communities' because emotion is recognised as profoundly social and contagious. ${ }^{15}$ The question about the qualitative leap in the production of consciousness from physiology of the human brain has then its macro analogy. But how do cities generate a consciousness of themselves from their materialities (biological, physical and chemical). To that question I now turn.

To begin materially with any built up environment is to begin simultaneously with the physicalities of natural and adapted space, that is, place, and a name. What's in a name? If I speak of Washington or New York. If I speak of Liverpool, Manchester or Paris. These are all names of places; they are all nouns. But they are also metonymies. That is: they are nouns which sum up large and complex operational organisms - like the White House sums up all the functions of the Presidency of the United States. The names bear with them multiple and irreducible associations tied into histories

14 GWF Hegel, Phenomenology of Spirit, trans. AV Miller (Oxford: Oxford University Press, 1977), pp 58-103 on "Consciousness" and pp 104-38 on "Self-Consciousness".

15 See Linda Woodhead and Ole Riis, A Sociology of Religious Emotion (Oxford: Oxford University Press 2011). 
and cultural memories. They are not simply conurbations, nodal points on national and international maps. They are not simply places where people live and work, dwell and congregate. They are not just sites of commercial enterprise or industrial manufacture. They are conglomerations of corporations - governed bodies composed of numerous other bodies, each with overlapping jurisdictions: physical bodies, social bodies, religious bodies, and institutional bodies. All of these bodies are material. And as corporations they take on personalities that become conscious of themselves. In fact, many of them become legal persons that can be held to account with liabilities. They can be taken to court, sued and exonerated. The famous British historian Asa Briggs established a reputation with a book published in 1954 entitled Victorian People in which he chose to study a number of Victorians whose "attitudes and careers reflected and directed the tendencies of the period". ${ }^{16}$ He consolidated that reputation in 1963 with the publication of a companion volume, Victorian Cities in which he chose to study a number of Victorian cities and the way they developed images of themselves, and also cultivated attitudes, careers and professional bodies that reflected and directed the tendencies of the period. ${ }^{17}$ His work suggests a profound association between individual persons and corporate personalities; between subjective consciousness and corporate consciousness. What links the two material conditions - physiological and civic - is imagination and image. ${ }^{18}$ Asa Briggs: "It was the city rather than the wilderness that was beginning to dazzle the imagination of the nation." ${ }^{19}$ Not merely the importance of work drove people into the cities and led to their production and extension, cities offered something that provoked people's desires and dazzled their imaginations. They were cities of the imagination that inspired further cities of the imagination - like Batman's Gotham, for example. I tried to give an account of this allurement in the opening of my Cities of God volume ${ }^{20}$.

16 Asa Briggs, Victorian People: Reassessment of Persons and Themes, 1851-1867 (Chicago: University of Chicago Press, 1975), p 11. Originally published in 1953.

17 Asa Briggs, Victorian Cities: Manchester, Leeds, Birmingham, Middlesbrough, Melbourne, London (Penguin: Harmondsworth, 1968).

18 See Arthur M Schlesinger, The Rise of the City 1878-98: Urban Life and Urban Landscape (Ohio State University Press, 1999).

19 Asa Briggs, Victorian Cities, p 82.

20 Graham Ward, Cities of God (London: Routledge, 2000). 
Although I grew up in the city of Manchester and, for several years lived in London, nothing prepared me for my first trip to the US. I landed at night at the airport and took a taxi to the hotel. And it was as I was coming over the freeway that New Orleans sprang up before me. The urban sprawl was not in evidence - it was too dark. What manifested itself was a density of skyscrapers, neon-lit, fabulously conceived, rising straight from the flood plain in a Promethean act of self-assertion and self-assurance. And things only got better when I first visited New York, Chicago, Dubai, Singapore, Beijing and Kuala Lumper. These are cities conscious of the impression they make; the image they project. They are conscious also of how to change or modify that image; how to turn it into a brand name and how to advertise that brand name internationally in ways that attract further investment: of capital, of labour, of civic pride and civic service. As purveyors of an image, cities are implicated in their own myth-making; and the myth-making circulates around the concept of their success. Civic aspiration is contagious and when its reputation is damaged or comprised it is concerned. As the song goes for New York: "If I can make it there I'd make it anywhere." As Nimrod stood before the elevation of the tower of Babel, so the ambitious stand before the wealth, power, confidence and energy of the city, and shout, "Let us make a name for ourselves" (Genesis 11.4). Observe the way transcendence and self-consciousness present themselves in this early account of civic living: "Let us build ourselves a city and a tower." Gaining height, seeing from an exulted perspective (from above) and conceiving the possibility of such a perspective (from below), is part of a city's dream for immortality. Immortality and monumentality are interwoven in our skylines. There is another side to the city's image, as we will see, but the ambitious see this less clearly. Asa Briggs again: "'What may be called the 'image' of a particular city depended... not only upon facts but upon the imaginative power with which people arranged the facts in a pattern." ${ }^{21}$ People didn't just see; they saw as - and projected those aspirations and imaginations into the materialities they worked with. ${ }^{22}$

21 Ibid, p 87.

22 On "seeing $a s$ " and its relation to belief and imagination see Graham Ward, Unbelievable: Why We Believe and Why We Don't (London: IBTauris, 2014). 
Let me say at the outset, and demonstrate as we go along, the image and myth-making of cities reveals a profoundly theological imagination - even if, as in the example of Babel, the theology can become inverted (as a form of idolatry). Cities are not just self-conscious; they are forms of consciousness seeking to understand, reaching towards a meaning that eludes them. That is why the consciousness they invoke is mythically conceived. All cities lie in the shadows cast by those mythic cities that dominant western culture and therefore the western imagination: Babylon, Sodom, Gomorrah, Jerusalem, Athens and Rome. And each of those cities bears a heavily religious freight. This may take the form of the paganism of Babylon, the civic religions of both Athens and Rome or the Judaeo-Christianity of Jerusalem - but all of them are rooted in ancient texts testifying to the blood of sacrifices, the work of gods and the construction of temples and the practices of cults. They are cities as Stargates - entrances into legendary pasts, impacting still upon our presents and inspiring our futures. In the building of our modern cities, founding fathers and mothers frequently drew comparisons between their own endeavours and those of the bearers of more ancient traditions. The Oxford aesthete, Walter Pater, William Morris and Oscar Wilde all called London a modern Babylon; Blake spoke about building Jerusalem among the dark satanic mills; and the Disraeli, in his novel of 1844, Coningsby, in which the narrator visits Manchester, reflects: "a great city, whose image dwells in the memory of man, is the type of some great idea. Rome represents conquest; Faith hovers over the towers of Jerusalem; and Athens embodies the pre-eminent quality of the antique world Art." ${ }^{23}$ In speaking about the nation and the development of nationalism, Benedict Anderson coined the phrase 'imagined community', and defined this as a production of a sense of national belonging that processes like census-gathering, newspapers and museums create. ${ }^{24}$ If my analogy holds between the subjective consciousness (and self-consciousness) and civic consciousness (and self-consciousness), then the nation is a further extension of that analogy, and names like 'Japan' or 'Egypt' and 'England' function as similar, complex metonymies, as 'Rome', 'Paris' or 'Cape Town'.

23 Tristram Hunt, Building Jerusalem: The Rise and Fall of the Victorian City (London: Weidenfeld \& Nicolson, 2004), p 199.

24 Benedict Anderson, Imagined Communties: Reflections on the Origin and Spread of Nationalism (London: Verso, 1983). 
People belong to an imaginary community when the face to face encounter with others is no longer possible, when, across distances, a state needs still to generate a 'belonging', an idea of a corporation, a national and a political body. Such a community is 'imagined' in the sense that it is generated by human symbol-making and sustained by feeding the imaginations of a certain people living within a certain locale. It is an imagination nurtured frequently by that most primary of national products, its language. ${ }^{25}$ Geographical boundaries do not necessarily concur with linguistic boundaries and hence the fights for independence and cultural identity rage - particularly in those parts of the world (Ukraine, Kosovo, Iraq) where colonisers have created borders with ruler and pencil.

The city is, as I said, a product of the imagination. The early Victorian and industrial cities of Britain were not simply the manufacture of local governments, civic mayors, city developers etc.; they were the product of novelists like Charles Dickens and Elizabeth Gaskell; early sociological studies by Mayhew in London and Thomas Carlyle; polemists like Frederick Engels; and painters like John Martin, and later, R.S. Lowry. But they are not entirely imagine communities in Anderson's sense because there is a concrete belonging that occurs within cities: the payment of a local tax; the registration of births, marriages and deaths; a domicile in a certain quarter; a traversing of the city's streets in going to work; a use of various civic amenities from parks to libraries, swimming pools to cinemas; a participation in civic activities like working at the university or being the governor of a local primary school. And continually, there remains faceto-face encounter with friends, family, colleagues, and other citizens. These contingencies compose the material conditions out of which the consciousness of a collective emerges. So the lived-city then is less imaginary than Anderson's national community. It is a continual negotiation between the imaginary and the sensed; empirical experience and its interpretation; seeing and seeing as. If we remain in one city for a time then our lives are mapped on to that city: here I was confirmed, there I took my first date for a coffee; here I had my accident and there God spoke to me etc. But since belonging is not just an animal thing (we have evolved as nations because

25 On the relationships pertaining to language, imagination and the theological questions of meaning they raise see Rowan Williams, The Edge of Words: God and the Habits of Language (London: Bloomsbury, 2014). 
we have learnt that survival is facilitates best by group-dependency), but a theological thing (we were made as human creatures in the image of God and therefore as social animal orientated towards community because God is communal in God's intra-trinitarian nature). As such our civic belonging is and remains profoundly biological, cognitive, affective and theological; and therefore theological intimations are given expression in our creation, inhabiting and building of cities. As I put it once: we may have been creatures created in a garden but our destiny is a kingdom and a city, to quote the Letter to the Hebrews, whose foundations are God-laid, God-designed and God-constructed (Hebrews 11.10).

Belonging now to several generations of urbanites, habit has dulled the sense of the city as a different kind of living experience, a laboratory in which new forms of sociality were cultured. The French historian, Ferdinand Braudel, working within the city-as-a-machine trope once wrote: "Towns are like electrical transformer. They increase tension, accelerate the rhythm of exchange and ceaselessly stir up men's lives." ${ }^{26}$ And so the early modern city, birthed in Britain, had never been experienced by human beings before. Open the books by urban and historical geographers treating the making of the modern European city and the facts presented are startling. If we take the years 1800 to 1910 , just over a century, then we find that the population of London grew from 1.1 million to 7.3; Paris from 547, 000 to 2.9 million; and Berlin from 172,000 to over 2 million inhabitants. In the States figures are even more astonishing: New York grew from 60,000 to 4.8 million and Chicago from nothing because the land was uninhabited until the middle of the nineteenth century to 2.4 million. ${ }^{27}$ Modernity's great symbol is the rise of the metropolis. The metropolis is modernity materialised - both for good and for evil.

If we associate modernity today with the rise of the secular consciousness, then this has to be qualified. It has to be qualified by what I have already pointed out: the mythic imaginations at work in the conception of cities and the theological resonances evident. Certainly as the great cities of the

26 Ferdinand Braudel, Capitalism and Material Life 1400-1800 (London: Fontana Books, 1973), p 382.

27 As overall guides, see Andrew Lees and Lynn Hollen Lees, Cities and the Making of Modern Europe, 1750-1914 (Cambridge: Cambridge University Press, 2007); and Richard Dennis, Cities in Modernity: Representations and Productions of Metropolitan Space, 1840-1930 (Cambridge: Cambridge University Press, 2008). 
modern world were fashioned they were not viewed in reductive secular terms. For with the rise of the British city came a zeal for moral improvement and a different kind of evangelism than that which dominated the end of the eighteenth century with Methodism. There were more churches built in Victorian Britain than in any other period of British history; and the majority of them were built in cities. All of the major civic developments in Victorian cities are owed to two enthusiasms: the enthusiasm for free trade, on the one hand, and the enthusiasm of the Nonconformists (particularly Baptists, Unitarians and Quakers) to spread what in Birmingham was called a 'civic gospel'. Max Weber's thesis that the rise of capitalism, and global trade, was associated with Protestantism is strongly supported by the history of the modern city. But Weber does not pay enough attention to the explicitly theological readings of the phenomena industrial capitalism unleashed. A theologically inspired moral vision informed cities conscious of the name they were acquired and the hopes for their destiny. They were, to use the title of chapter in Italo Calvino's fiction Invisible Cities, cities of desire. It was the moral nature of this vision that pursued clean streets, advanced sewage disposal, gas-lighting, and the maintenance of public order, the opening of parks and libraries, and the appointment of civic medical officers. Town Halls and Stock Exchanges replaced cathedrals as the city's grandest buildings, and one might say this topographical displacement advanced a notion of the secular. But these buildings too were constructed to transcend the individual citizen and both create and require a consciousness of corporate allegiance and responsibility. Behind this moral vision was an equally moral and theological fear: sin was never so present as in the slums, garrets and cellars of cities whose numbers very quickly outgrew sanitary amenities, housing provision, early local government and policing. The industrial cities of northern Britain became international attractions of a highly lurid nature to political scientists like de Tocqueville and travel writers like the poet Robert Southey who outdid each other in descriptions of the bestiality that found in the low-life areas of emerging metropolises: shit ankle deep in the lanes between ramshackle housing, rivers torpid with waste and industrial chemicals, and water supplies bubbling with cholera, typhus and miasmatic gases. ${ }^{28}$ We should take note of what is happening here: the desire to rise above the material, 
to be purified of the physical and the physiological. The desire to transcend towards an elevated consciousness was theological inflected: moral collapse was theologically viewed as the very manifestation of human sinfulness and depravity in cities where drunkenness, prostitution, incest, murderous brawling, theft and gangland warfare were rife. Cities were fermenting atheism that much was true. And that's why the Victorians built so many churches: buildings as bulwarks against the brutal materialities associated with the bestial. Nevertheless, this wasn't secularism as such just civic degradation utterly devoid of religious feeling or sentiment being seen recorded and evaluated from a theological point of view. What Engels saw as the conditions ripening for revolution (a revolution that never happened), the Nonconformists saw as human nature in its most primal state of original sin; sin that had to be kept at bay because human suffering fed human depravation. It was upon a theological basis that not only civic development took place, but also the joists of the modern secular state were hoisted. Protestantism had always been an urban phenomenon since Luther got the backing of the German city-states, and in the development of the modern city "the most influential members of urban civil society invariably belonged to the Nonconformist congregations." 29 These people knew, from their bitter experiences of suppression, the need for religious tolerance and civil peace, and so a "free press independent of the state censors was a core component of the Nonconformist political agenda." 30 In the explosion of municipal presses that took place as the modern city established itself, Nonconformist communities were at the forefront.

So let's recap on what I have argued so far before we jump to where we are now. First, the civic imagination is still haunted by the myths and images of ancient, often Biblical cities. Secondly, around the image of the city is developed a sense of a corporate personality that gives expression to the civic imagination as it sets about making a name for itself. The work of 'making a name' is an economic, social and political production; it is brand-making, and brand-making always involves myth-making. Thirdly, the brand a city fosters, the myth-making in which it is involved, has been, profoundly, the work of a theological imagination - and that imagination

29 Tristram Hunt, Building Jerusalem, p 141.

30 Ibid, p 172. 
leaves its marks everywhere upon the cityscape today. Fourthly, even some of the key moments in the development of secularism - the move from church to civic responsibility, from church to civic provision, respect for the dignity of the human person in terms of human rights and the freedom of the press - were theologically inspired and theologically driven. But there is a fifth and final point to make. Religious and civic freedoms, the advance of religion and the advance in civic provisions were both predicated upon, socially and culturally, free trade. In other words, globalisation is as much written into the fabric of our cities, as the theological imagination and the secular civic realm. And so, to expand our analogy even further: subjective consciousness becomes collectively civic consciousness, national consciousness and international consciousness. We cannot divorce one of these four constituents from the others. It is on the basis of these five points that I would like to sketch two contemporary trajectories: the theology still present in today's cities and the theology increasingly present in the manifestations of globalisation in those cities.

The theological key to the image and myth-making of the modern city is eschatology. The Western imagination benchmarks all cities with respect to the celestial city, particularly the Protestant Western imagination. What changed in the nineteenth century conceptions of eschatology was a certain emphasis with respect to time. Theologically, there was in the Church Fathers if not in John's Gospel, an eschatological tension between the kingdom now and the kingdom to come which, for most, was deemed an afterlife event: no one could build the New Jerusalem on earth. The realisation of the kingdom came with the resurrection of the body, the resurrection of the dead; it was, is and will be a God-given event. Churches, monasteries and convents were analogies of the heavenly city, imagined possibilities of afterlife living in the kingdom of God; but they were never conceived in terms of the foundations for establishing the kingdom of God here on earth. The eschatological was then not a part of the continuum of secular time; it wasn't a future event that the progress of history would bring about. The coming of the kingdom was both a perfection of God's providential operations within history and the manifestation of something yet to be revealed. This temporal tension between what was being realised and what was yet to be revealed, this dichroism in time between the temporal and the eternal, changed with a focus in modernity upon the modo - the now, 
the present continuous. The aspirations of the early modern city designers - whether architects, sewage engineers, municipal patriarchs, railroad builders or early city developers - were all utopian: aimed at bringing the heavenly down to the earthly. The ideals of clean, well lit, secure streets, spacious public squares, attractive public gardens, established cultural amenities, and monumental and aesthetically pleasing public buildings all constituted a civic gospel that the proliferation of churches and chapels turned into the Christian gospel. Work for the kingdom to come was to begin now with a good dose of Victorian self-improvement: God helps those who help themselves. With the shift towards the importance of the modo, the modern and the present continuous, the gap between realised and deferred eschatology considerably shortened. The modern city was conceived as a home for angels and the fashioning of the angelic. And later this conception inspired skyscraper developments that could see the city from a panoramic perspective, offering a transcendence closer to omniscience than that available on pounding the pavements. As I said, Babel already foreshadowed this development; towers were transcendence taking architectural form. And later still, as technology (a driver always for both the expansion of globalisation and the development of the city's image of itself) provided new forms of glass, concrete and steel girders, the conception of a city for angels became even more realised - as architectural forms were carved out of light and space. Cities craved skylines; citizens craved views of skylines; and the skyline announced an amalgam of religion, utopianism and fantasy. They formed a vast neon advertisement, the city's brand name. And in the clamour of this great civic bravado, the churches and the chapels were left behind or rather dwarfed by a fiercer Promethean desire as the city launched itself towards the stars; the glitter, the glamour, the adulation, and the fame of internationalism.

Cities are nodal points in a network relays and exchanges, economic and material, that provides the infrastructure for globalisation. In the global system we have now, many of the operational elements are the same as those that modernised the early cities: telephones and telegraphing give way to email and on-line access; horse-drawn carriages have become container trucks and cars; and train lines are supplemented with motorways and airports. Activity speeds up as space becomes flow and distance shrinks; the temporal takes on aspects of the eternal: the instantaneous, the 
immediate - all of which add to the sense of a realised eschatology. In fact, one might suggest, technology, always haunted by dream of divine powers (omnipotence), begins to develop along the line of realising the properties of what was once held to be only available to the divine. ${ }^{31}$ Hence it should come as no surprise that globalisation can itself be conceived as a theological project and inflected with the same theological ideas found in the city: the eschatological orientation towards the future perfect and the fabrication of transcendence. As the city aspires to become pure light, air and space so with globalisation comes a dematerialisation. As the city is involved in a myth-making about its own personality so globalisation spins a myth out of abstractions and universalisms. As I pointed out in my book The Politics of Discipleship, ${ }^{32}$ detraditionalized religion (which is what Protestant Nonconformism is), a religion without past or future, and it finds itself expressed in globalisation as a cultural, not simply economic, phenomenon in six particular ways.

First, it invokes a new vision of infinite freedom - freedom understood economically as being able to pursing one's own desires, control one's own destiny liberated from dependencies, political and social, and local needs. Salvation is total emancipation. Secondly, it fosters belief in an eternal sustainability promising unlimited consumption. It is not just that this kingdom (and its everlasting banquet) can be established and brings history to an end, but also that a perpetual, progressive motion will govern this kingdom. Thirdly, this motion is determining and inevitable; it is a destiny. It is a transcending force beyond human control that human beings have to embrace: not so much a Providence as a pagan understanding of a fate to be loved. Fourthly, this force is dematerialising. Coins and notes are the nominal tokens of a sovereign power that is ultimately ungraspable. There is a metaphysics of money; an appeal to a transcending ontology. The less we see of the actual coins and notes that gave us the illusion of money as a natural substance, the more transactions concern electronic figures transcribed in cyberspace, the more the material is transcended. The eclipse of time and space in this new internationalism and the access

31 For a development of this line of thinking see Michael S Burdett, Eschatology and the Technological Future (London: Taylor and Francis, 2015).

32 Graham Ward, The Politics of Discipleship: Becoming Postmaterial Citizens (Grand Rapids: Baker Academic Press, 2009). 
to such an eclipse via the internet assist in this dematerialisation. Fifthly, globalisation offers an all-encompassing worldview in which credit and credo are again inseparable. In his landmark book Capitalism and Freedom, Milton Friedman points out that in a government's monetary control and fiscal policy there are "mythology and beliefs required to make it effective." 33 What we believe or are led to believe financially is directly related to how substantial the beneficial changes are to our lives that we register. The mythology and beliefs generated around globalisation, the effects of which we can see all around us, do not just present us with an historical process, but rather with a universalist vision of the truth about human beings and the civilisations they nurture and are nurtured by. This new universalism is an outworking of a trajectory that began to view 'religion' as a generic category and 'humanism' (Charles Taylor's 'exclusive humanism' ${ }^{\prime 3}$ ) is its secular correlate. Globalisation becomes inseparable from globalism. Together they announce a truth about a cosmological community that recognises what the producers of the 2005 Live 8 set out to proclaim: our radical intradependence. It is a utopian vision of an international community stable and beyond conflict (see later comments on the Christian conception of the Kingdom of God in chapter seven). Sixthly, finally, it is a moral vision that is ultimately Protestant in its orientation; the amor fati, though an intense discipline (as Nietzsche recognised) will bring about the rejuvenation of an economy and its people. This is the message still being given the Third World countries by the G20, who have the power to cancel the vast burden of their debts. It is this 'religious' eschatological undertow to globalisation that is turning Weber's disenchantment of the world through rationalisation into a new re-enchantment. And in doing this it is helping to reverse the processes of secularisation founded upon an adherence to the material and the rational. The economist John Rawston Saul has recently written: "[W]hat we are dealing with here is a type of religious fundamentalism." 35

33 Milton Freidman, Capitalism and Freedom (Chicago: University of Chicago Press, 1962), p 42.

34 See Charles Taylor, A Secular Age (Cambridge, Mass.: Harvard University Press, 2007).

35 The Collapse of Global Capitalism (London: Atlantic Books, 2005), p 48. 
I'm going to end this reflection on the city, corporeality and consciousness, and their theological correlates, where I began - in the birth of the modern city. This is my city, Manchester; one of the first modern cities of a modern world born out of the industrial revolution. In 1848, Sir Robert Peel, repealed the Corn Laws by which the state fixed the price of certain goods in favour of the landowners. Their monopoly was broken, prices fell, and imports surged. The gates were open for laissez-faire economics; the same economics driving globalisation. Nowhere had the campaign of the AntiCorn Law League been stronger than in Manchester and so the middle classes celebrated the victory in that city by erecting The Free Trade Hall, one of its finest public buildings. The civic gospel always bore an economic face. The city set its sight on furthering a globalization of trade that had been gathering pace since the fifteenth and sixteenth century voyages of discovery and the colonialism that followed. It was the home of the Hallé orchestra and a public theatre for educational lectures; its task was ultimately theological - self-improvement. And today it is a five star hotel - the "Radisson Edwardian".

What we have survey points to a tension that is profoundly anthropological (and theological): rooted in our physiologies conscious emerges, mind that is different from but not unrelated to brain. With consciousness comes symbolization. With symbolism, and imagination, there is a pull away from embodiment towards that which transcends. The city, the nation, the global are all collective extensions of that capacity to transcend; a capacity that is profoundly theological. We seem to be searching for a meaning that our symbolising both installs and demands, and the resolution for the tension between the visible and felt and the invisible and inferred. We seem to be scanning the horizon - welcoming a future that is always arriving and waiting for a future that is always deferred. Such a condition, written into our city developments, nation building and global concerns is theological in a way that belies the ostentations of secularism. 